\title{
Language, Exegesis, and Creative Writing in Chronicles
}

\author{
Jan Joosten \\ University of Oxford \\ joosten@unistra.fr
}

\begin{abstract}
The verb התחפש is well-known in the meaning "to disguise oneself," but this meaning does not seem to fit its context in 2 Chron 35:22. Why would Josiah disguise himself when going to battle with Necho? In this paper it will be argued that the verb was borrowed from the story on Micah ben Yimlah (1 Kgs 22:30) in the course of the Chronicler's reshaping of Josiah in the image of Ahab, but that its semantics reflect a later interpretation of some elements in that story. The later interpretation is attested independently in the Peshitta and the Vulgate where התחפש is rendered as "to arm oneself."
\end{abstract}

\section{Keywords}

intertextuality - pseudo-classicism - theological interpretation

\section{Introduction}

Hebraists like H. L. Ginsberg have described the history of Biblical Hebrew as the succession of a "Golden Age," corresponding to the monarchic period, and a "Silver Age" during and after the Babylonian exile. ${ }^{1}$ In more recent writing, such evaluative terms are frowned upon. ${ }^{2}$ Indeed, the aesthetic judgment runs

1 See H. L. Ginsberg, "The Northwest Semitic Languages," The World History of the Jewish People. First Series: Ancient Times, vol. 2 Patriarchs (Edited by Benjamin Mazar; Tel-Aviv: Massada, 1970), 102-224, 112.

2 See Mark F. Rooker, Biblical Hebrew in Transition: The Language of the Book of Ezekiel (Jsots 9o. Sheffield: JSOT, 1990), 14. 
the risk of missing the point. The essential difference between the Classical Biblical Hebrew (свн) of the Enneateuch and the Late Biblical Hebrew (LBH) of the books of Chronicles, Ezra-Nehemiah, Esther, Qoheleth and Daniel is not that the former is more elegant than the latter-although it often is. ${ }^{3}$ Nor is the essential difference that the "LBH" corpus is more tainted with Aramaic influence, although this too is certainly true. The essential difference is rather that the later corpus betrays a different attitude to language. While most of the prose texts in Genesis-2 Kings draw on dialects of living Hebrew, the later books borrow much of their language from older writings.

I do not wish to suggest that the entire Pentateuch and Former Prophets existed from the exilic period in the form known to us. It is extremely difficult to know when the various books of the Hebrew Bible crystallized in the form that has come down to us. But even without this knowledge, it is easy to observe that the postexilic books exhibit a dense web of intertextual connections to earlier writings: Chronicles follows, and rewrites, Samuel-Kings; ${ }^{4}$ Esther echoes the Joseph story at every step; the apocalyptic chapters of Daniel build on prophecies contained in the book of Isaiah. ${ }^{5}$ The language of the late books is full of expressions that seem antiquated and appear to have been lifted wholesale from earlier texts. ${ }^{6}$

The active re-use of classical expressions in religious writings of the later period is not purely literary in nature. It testifies to a group increasingly defining

3 This is of course a subjective judgment and as such perhaps futile. Arguably Esther and Qoheleth belong to world literature the same way Genesis and Isaiah do.

4 From the beginning of historical-critical investigation of the Hebrew Bible, Chronicles has been recognized as a rewriting, by and large, of Samuel-Kings. This classical view was criticised some decades ago by Graeme Auld, who argued instead that Chronicles and SamuelKings depend on a common source that has not been preserved. Several other OT scholars have followed in Auld's footsteps. In the new approach Chronicles and Samuel-Kings are usually regarded as more or less contemporaneous works both dating to the Persian period. Recently, however, the classical view has again rallied the support of many important scholars. The rewriting hypothesis explains most of the facts much better than the independentdevelopment-from-a-common-source hypothesis. For discussion see e.g. David Carr, The Formation of the Hebrew Bible. A New Reconstruction (Oxford: OUP, 2011), 57-701, in particular 74. Strong support for the later date of Chronicles comes from its language. Whereas SamuelKings on the whole reflects the classical Hebrew of the Pentateuch, Chronicles clearly represents late biblical Hebrew.

5 See H. L. Ginsberg, "The Oldest Interpretation of the Suffering Servant," VT 3 (1953), 40o-0o4.

6 A good example is the Hebrew term שׁטְר "officers," used 18 times in the Pentateuch and Joshua, never in Samuel-Kings, but then six times in reference to officers of the royal period in Chronicles. As Elitzur has remarked: "Its use in Chronicles is probably artificial, influenced by the Pentateuch." See Yoel Elitzur, "The Interface Between Language and Realia in the Preexilic Books Of The Bible," Hebrew Studies 59 (2018), 129-947, 135. 
their own identity in function of a body of texts. Judaism is turning into a book religion. The authors of the later books had read, and studied, texts that now figure in the Pentateuch and Former Prophets. Their deep engagement with earlier texts generated a special type of language, which intended to link up with Hebrew as it had been practiced at an earlier period. The earlier texts were viewed as authoritative, if not canonical. Jews drew upon the classical texts in order to tell their own story. This is a long process that sets in at some point in the Babylonian period and progresses beyond the latest biblical books into the Dead Sea Scrolls.

In the present paper we will look at a single example of this textual dynamic in the book of Chronicles.

A Remarkable Linguistic Usage in 2 Chron 35:22

In 2 Chron 35, it is told that King Josiah goes out to block Necho, the King of Egypt, who is on his way to make war against the Babylonians. ${ }^{7}$ Necho sends his emissaries to inform Josiah that his war is not with him, he is hurrying on to Karkemish. But Josiah persists:

2 Chron 35:22

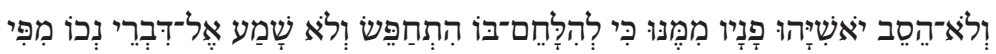

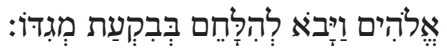

Josiah would not turn away from him, but disguised himself in order to fight with him. He did not listen to the words of Necho from the mouth of God, but joined battle in the plain of Megiddo (NRSv, emphasis added).

The clash leads to the tragic death of Josiah. Archers shoot him in his chariot and he is taken back to Jerusalem to die.

The hithpael of the verb חפש "to seek" is attested in several passages in Samuel and Kings in the meaning "to disguise oneself." ${ }^{\text {Th }}$ This meaning is

7 See in addition to the commentaries Zipora Talshir, "The Three Deaths of Josiah and the Strata of Biblical Historiography (2 Kings XXIII 29-90; 2 Chronicles XXXV 20-0; 1 Esdras I 23-31)," VT 46 (1996), 213-336; David Janzen, "The Good and Bad Deaths of Josiah: Prophecy and Peace in Chronicles," in idem, Chronicles and the Politics of Davidic Restoration: A Quiet Revolution (London: Bloomsbury T\&T Clark, 2017), 138-857.

8 The attestations of this verb are 1 Sam 28:8; 1 Kgs 20:38; 22:30 (twice); Job 30:18; 2 Chron 18:29 (twice); 35:22. 
etymologically plausible, implying something like "to let oneself be sought for," and fits the contexts in which the verb occurs well. ${ }^{9}$ For example, in 1 Sam 28:8,

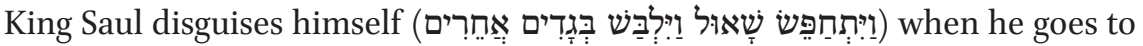
consult the necromancer of Endor, who then nevertheless recognises him by help of Samuel's spectre.

In our passage, most English versions translate התחפש similarly as "to disguise," and this is also the meaning proposed in the standard dictionaries. ${ }^{10}$ But a moment's reflection will show that it makes little sense. Why would Josiah disguise himself when going to war with Necho?"1 In what follows, the text states that when the two armies clash, the Egyptian archers take aim at Josiah, wounding him fatally. This again shows that the notion of disguise is alien to the context.

Several ancient versions seem to diverge from the Hebrew. The Septuagint

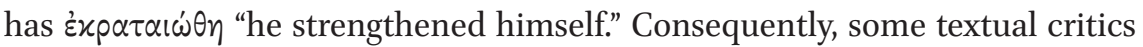
have argued that the earlier reading was התחזק "he strengthened himself."12 But it is hard to explain how or why this simple reading was changed into the problematic Hebrew that has come down to us. The Septuagint variant would seem to be facilitating. It confirms that the meaning "he disguised himself" is not suitable, but does very little to solve the problem of the semantic mis-

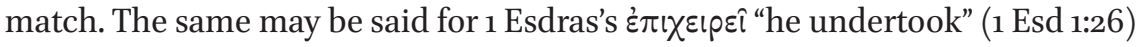
and the Vulgate's praeparavit "he prepared himself." Conjectural emendations have been proposed, but they are unlikely. ${ }^{13}$ It seems the MT needs to be kept. But what does it mean? ${ }^{14}$

9 A possible exception is Job $30: 18$, but this verse is difficult and the meaning of the verb unclear.

10 So also Janzen, "Good and Bad Deaths," 143.

11 Some commentators have argued that the verb does suit the context, but their explanations appear forced. E.g. Kiel suggests as one possibility that the subject of the verb is not Josiah but Necho. The meaning would be something like "he pretended" to be on his way to Karkemish but was in reality intending to "fight him," Josiah. See Yehuda Kiel, Sepher Divrey Hayyamim (Daat Miqra; Jerusalem: Mossad Harav Kook, 1986), 927. But this seems highly unlikely: the usual meaning of the verb is "to disguise oneself," not "to pretend"; also the subject must be Josiah in light of the intertextual connection to be explored below.

12 See Dominique Barthélemy, Critique textuelle de l'Ancien Testament I (ово 5о/1; Fribourg: Éditions Universitaires/Göttingen: Vandenhoek \& Ruprecht, 1982), 519.

13 Rudolph proposed to repoint the text and read a shin instead of a sin and to understand the form as: "he freed himself" (from the root חפש "to be free"), see HAL I, 328. This proposal is without merit: the hithpael of חפש is not attested elsewhere, and the meaning "he freed himself" hardly fits the context.

14 Talshir has argued that the verb means "to seek (to fight) despite the warnings" "Three Deaths," 219). Although this is not the meaning that seems most likely to me, the 
I will suggest that the verb means "to arm oneself" in our passage. The argument for this interpretation will have to be put off until we have explored some intertextual echoes in the story.

\section{Josiah's Death in Chronicles Modelled on Ahab's Death}

An important aspect of our passage is the way it echoes an earlier story. As many exegetes have noted, the Chronicler has modelled Josiah's death upon that of Ahab in 1 Kgs 22 (par. 2 Chron 18):15

1 Kgs 22:30-0 $5^{16}$

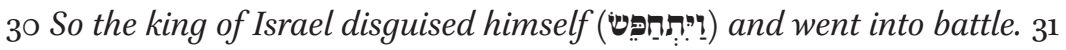
Now the king of Aram had commanded the thirty-two captains of his chariots, "Fight with no one small or great, but only with the king of Israel." 32 When the captains of the chariots saw Jehoshaphat, they said, "It is surely the king of Israel." So they turned to fight against him; and Jehoshaphat cried out. 33 When the captains of the chariots saw that it was not the king of Israel, they turned back from pursuing him. 34 But a certain man drew his bow and unknowingly struck the king of Israel between the scale armor and the breastplate; so he said to the driver of his chariot, "Turn around, and carry me out of the battle, for I am wounded

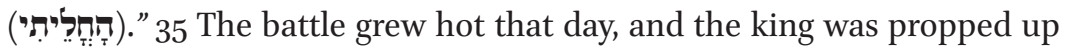
in his chariot facing the Arameans, until at evening he died.

Like Ahab, Josiah is killed in his chariot by an arrow, and like Ahab he tells his

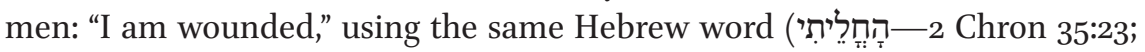
1 Kgs 22:34/2 Chron 18:33); like Ahab, his men take him away from the battle before he dies. The verb התחפש is another element confirming the analogy. ${ }^{17}$

proposal correctly implies that the verb means something different in 2 Chron 35:22 and in 2 Kgs 22:30.

15 The first one to observe the connection between the two texts seems to have been Torrey. See Charles C. Torrey, Ezra Studies (Chicago: University of Chicago Press, 1910), 220-021.

16 The story of Micah ben Yimlah was taken over from 1 Kgs 22 in 2 Chron 18 with very few changes. In what follows I will systematically relate to $1 \mathrm{Kgs} 22$ which is the source text for the Chronicler. As is well known, Ahab is generally called "the king of Israel" in this chapter, and an earlier form of the story may have had a different king in mind. But this is not relevant to our present concerns.

17 More (and more tenuous) analogies are explored in Janzen, "Good and Bad Deaths": the king goes to war in spite of an ambiguous prophecy to the contrary. 
These echoes of the story of Ahab are not present in the Kings version of Josiah's demise. They are part of the specific literary and theological shape the Chronicler gave to his account. ${ }^{18}$

2 Kgs 23:29 In his days Pharaoh Necho king of Egypt went up against the king of Assyria to the river Euphrates:

and king Josiah went to meet him;

and Pharaoh Necho killed him at Megiddo, when he had seen him.

30 His servants carried him in a chariot dead from Megiddo, and brought him to Jerusalem, and buried him in his own tomb.
2 Chron 35:20 After all this, when Josiah had prepared the temple, Necho king of Egypt went up to fight against Carchemish by the Euphrates:

and Josiah went out against him. 21 But he sent ambassadors to him, saying, What have I to do with you, you king of Judah? I come not against you this day, but against the house with which I have war; and God has commanded me to make haste: forbear you from meddling with God, who is with me, that he not destroy you. 22 Nevertheless Josiah would not turn his face from him, but disguised himself, that he might fight with him, and didn't listen to the words of Necho from the mouth of God, and came to fight in the valley of Megiddo. 23 The archers shot at king Josiah; and the king said to his servants, Have me away; for I am sore wounded. 24 So his servants took him out of the chariot, and put him in the second chariot that he had, and brought him to Jerusalem; and he died, and was buried in the tombs of his fathers.

18 Williamson has argued that the rewriting of Josiah's death in 2 Chron 35:20-07 is not, or not wholly, due to the Chronicler but was already present in a reworked version of 2 Kgs 23:299o which the Chronicler used as his source. See Hugh Williamson, "The Death of Josiah and the Continuing Development of the Deuteronomistic History," VT 32 (1982), 242-247. This argument has not been received in later exegetical writings, see notably Talshir, "Three Deaths" (with discussion of earlier criticisms of Williamson), to my mind rightly so. 
Why the Chronicler assimilated the story of Josiah's death to that of Ahab is not immediately clear. There was a general similarity between the two events even in the earlier account in Kings: both Ahab and Josiah are killed while confronting a foreign army and then carried off in their chariots. ${ }^{19}$ If the Chronicler perceived an analogy, he may have felt free to fill in some details of the Josiah story from that of Ahab. The passage gives insight into the art of historical writing as practiced by the Chronicler.

But art and the joy of exploring intertextual connections cannot fully explain the rewriting. There is also a theological aspect. While Josiah was so to speak the "best king of Judah after David," Ahab was not only a king of Northern Israel but also a notorious apostate and abuser of his royal power. The implicit comparison of Josiah to Ahab suggests that something in Josiah's last royal act was somehow "Ahabic" in nature: Josiah behaved in an unfaithful and arrogant manner. The intertextual connection contributes to the Chronicler's effort to explain the righteous King's ignominious death. ${ }^{20}$

As was indicated above, the verb התחפש is one of the indications in 1 Chron 35 of the intertextual connection to $1 \mathrm{Kgs} 22$. In $1 \mathrm{Kgs} 22$ the verb clearly does mean "to disguise oneself":

1 Kgs 22:30 (cf. 2 Chron 18:29)

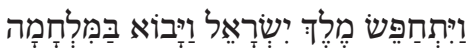

And the king of Israel disguised himself, and went into the battle. ${ }^{21}$

The notion of disguise makes sense here. As is explained in the near context, Ahab wanted to trick the Aramaeans. ${ }^{22}$ The ruse worked at first-the

19 As Talshir points out ("Three Deaths," 215), 2 Kgs 23:29 does not necessarily imply Josiah went out to battle against Necho. Chronicles, however, certainly understood the text in this way.

20 Josiah's arrogance and disobedience may be referred to more explicitly in 2 Chron 35:22 where the text states that: "(Josiah) did not listen to the words of Necho from the mouth of God." On the ambiguity of this prophecy, see Janzen, "Good and Bad Deaths."

21 The verb occurs twice in this verse, first in Ahab's proposal, then in the narrative.

22 The motif is somewhat obscured in the textual history of 1 Kgs 22:30, see BHs. The logic of Ahab's proposal would seem to require the reading: "and you, put on my clothes" (ואתה 
Aramaeans didn't recognize Ahab - although it almost backfired upon his ally, Jehoshaphat, King of Judah. In the end, however, a stray arrow accomplishes Ahab's destiny.

The presence of the verb התחפש in 1 Kgs 22 explains its use in 2 Chron 35, but it gives no help in identifying the meaning of the verb in the latter passage. In the Chronicles passage, the notion of disguise is not suitable. Nor should one think that the verb was simply copied from the source text, without interest in the meaning. Instead a glance at the reception history of 1 Kgs 22 may prove helpful.

The notion of disguise is relevant to the story in $1 \mathrm{Kgs} 22$, but some versions nevertheless translate התחפשdifferently. Notably, the Vulgate and the Peshitta attribute to it the meaning "to arm oneself":

- The Vulgate of 1 Kings 22:30 translates one of the two occurrences of this verb as sume arma "take up your weapons."

- The Peshitta renders the Kings passage correctly as "to disguise," but in the Chronicles parallel, 2 Chron 18:29, the Syriac twice renders התחפש as 'ezdayyan "to arm oneself."

These do not seem to be random variants. The agreement of two versions between which there can hardly have been a historical connection suggests that the interpretation of התחפש as "to arm oneself" reflects an exegetical tradition. As it seems, there was an ancient reading of the story in 1 Kgs $22 / 2$ Chron 18 in which the verb התחפש was not interpreted as "to disguise oneself" but as "to take up arms." 23

Although "to take up arms" is not the meaning we today would attribute to this verb, one can understand why it would have seemed a good interpretation in antiquity. Two factors seem to be at play. Firstly, it is likely that the meaning of the Hebrew verb was forgotten early on. In LBH the only cases of the hithpael of חפש are the three cases in Chronicles (2 Chron 18:29 twice; 35:22), and in post-biblical Hebrew the verb is no longer attested. ${ }^{24}$ This indicates that fell into disuse after the Babylonian exile. Secondly, an ideological factor may have been at work. Later readers may have considered it unworthy of an Israelite king — even an apostate king like Ahab — to disguise himself before going into battle. Kings are not supposed to play tricks, but to ride into battle

לבש בגדי (ל), which is indeed supported by the Septuagint. The change reflected in the Masoretic text (“... and you, put on your clothes") may be due to the type of reinterpretation which will be argued for below in the next section.

23 This interpretation was not shared by all ancient readers. The Septuagint correctly understands the verb in the meaning "to disguise."

24 The piel is attested in Mishna Pes. 2:3 in reference to a dog "digging out" food, but the hithpael is not found in Mishnaic Hebrew. 
in full costume. Faced with a somewhat rare verb whose meaning was perhaps not well remembered, some of these later readers shied away from the meaning "to disguise" and opted for the meaning "to arm oneself."

These considerations make it possible to understand our verse in Chronicles. Indeed, the verse becomes crystal clear if the verb התחפש as applied to Josiah is understood not as "to disguise," but "to arm oneself":

2 Chron 35:22

But Josiah would not turn away from him, but armed himself in order to fight with him.

The semantic fit is impressive enough to suggest that the Chronicler himself intended this meaning. The new meaning was not an innovation of the Chronicler, it came down to him as part and parcel of the story of Ahab's death in battle. In fact, the reinterpretation of Ahab's actions, reflected independently in the Peshitta and Vulgate as seen above, was a preliminary stage enabling the Chronicler's use of the story in his rewriting of Josiah's demise. The Chronicler's Ahab was not the trickster who disguised himself so as to escape the Aramaeans' arrows, but the tragic king of the North who armed himself for battle. As such Ahab could serve as an exemplar for the good king Josiah, who came to a tragic end.

Note that the Targum of Chronicles correctly identifies this new meaning in our verse: התחפש is translated אשתני ואטקס בזיני קרבא "he changed (clothes) and equipped himself with weapons of war."25

Let us sum up the argument so far. At some time between the writing of the story of Ahab's death (1 Kgs 22) and the time of the Chronicler, the story was

25 The Targum to Chronicles has a double rendering in this passage, with the other rendering reflecting the meaning "to disguise." Gersonides (Ralbag, 1288-8344) also gives the meaning "to put on armour" (לבש כלי מלחמה), see Kiel, Divrey Hayyamim (above, note 11). 
reinterpreted in certain circles. Notably, the Hebrew verb התחפש in the earlier story was given the meaning "to arm oneself." This interpretation came down to the Chronicler together with the story which he found in his main source. In his rewriting of the account of Josiah's death, the Chronicler used the verb with the new meaning as one of the features indicating an analogy between the fate of Josiah and Ahab.

This scenario is hypothetical, but it draws strength from other cases where the Chronicler uses Hebrew expressions he found in his sources in a way that diverges from their original use:

- In the Pentateuch and Former Prophets, the expression מלא יד "to fill someone's hand" means "to ordain someone to a sacred office." Chronicles uses the expression in a different meaning, namely "to bring an offering." 26

- The noun מגרש in the Pentateuch means "pasture lands," but in Chronicles it seems to refer to Levitical cities. ${ }^{27}$

- The phrase לִ לְוֹא חָמָת originally designated a place named Lebo situated in the land of Hamath, and this is its meaning in the Pentateuch and earlier historical books. ${ }^{28}$ In later times, however, the first element was reanalysed as an adverbial phrase meaning "up to the coming (to)." This interpretation underlies the remarkable use of לִּבוֹא מִצְרַים "to the entering in of Egypt" in 2 Chron $26: 8 .^{29}$

Similar cases occur in other late books of the Bible and in Ben Sira. ${ }^{30}$ They grow more numerous in the Dead Sea Scrolls. ${ }^{31}$ Each case is arguably a bit different, but they all reflect an effort on the part of later writers to use the Hebrew language they had found in earlier writings. The usages are "pseudo-classical."

26 See Jan Joosten, "Pseudo-Classicisms in Late Biblical Hebrew," ZAW 128 (2016), 16-69, in particular $25^{-} 56$.

27 For this and some other possible examples, see Sarah Japhet, "The Supposed Common Authorship of Chronicles and Ezra-Nehemia Investigated Anew," VT 18 (1968): 330-071, in particular 348-850.

28 See Y. Aharoni, The Land of the Bible. A Historical Geography (London: Burns \& Oates, $\left.1979^{2}\right), 72$.

29 Joosten, "Pseudo-Classicisms," 26-67.

30 See Jan Joosten, "Pseudo-classicisms in Late Biblical Hebrew, in Ben Sira, and in Qumran Hebrew," in Sirach, Scrolls and Sages. Proceedings of a Second International Symposium on the Hebrew of the Dead Sea Scrolls, Ben Sira, and the Mishnah, held at Leiden University, 15-57 December 1997 (ed. Takamitsu Muraoka and John F. Elwolde; Leiden, Brill, 1999), 146-659.

31 Ten possible cases are enumerated in Ronald Hendel, Jan Joosten, How Old Is the Hebrew Bible? A Linguistic, Textual, and Historical Study (Anchor Bible Reference Library; New Haven, CT: YUP, 2018), 94-45. 
In an earlier article I have described pseudo-classicisms in terms of obsolescence, oblivion and reinterpretation. ${ }^{32} \mathrm{~A}$ rare word or expression used in early texts falls from use and its meaning is eventually forgotten. The expression is then interpreted on the basis of close study of the early texts in question, sometimes no doubt correctly but in other cases in a way that diverges from the usage intended by the original author. In the new meaning, the word or expression is then revivified in later texts.

\section{$7 \quad$ Conclusion}

Although this study has somewhat single-mindedly focused on one word in 2 Chron 35:22, it has shed light on various aspects of Hebrew writing in the Persian period.

First, creative writing. The Chronicler based his account of Josiah's anomalous death on the much shorter version in Kings. However, he added much material to address a theological question: why did Josiah, who was such a good king, die young? Various answers are suggested to this question. A somewhat explicit answer is that Josiah didn't listen to the word of God from the mouth of Necho. But there is also a more subtle, implicit answer: at the end of his life, Josiah behaved, very briefly, like Ahab. He rode to war without reason, and was killed in a providential way. His death was a punishment for his disobedience and his arrogance. In elaborating this answer, the Chronicler rewrote the story of Josiah's death in the image of the story of Ahab's death in 1 Kgs 22 / 2 Chron 18 . He explicitly referenced the earlier story by using a few rare words and expressions used there.

Second, exegesis. It is important to realize that the use the Chronicler made of the story of Ahab's death had been prepared in the interpretive tradition of the earlier text. 1 Kgs 22, a story on two Kings going to war against the Arameans for frivolous reasons, against the better counsel of Micah ben Yimlah, is elaborated with comical traits. The introduction of Micah's prophecy in the first part of the story (1 Kgs 22:7-78) is one of the most hilarious passages in the Hebrew Bible. The comedy continues when the kings go to war: Ahab behaves like a clown, and Jehoshaphat like a fool. Ahab's plan to disguise himself turns out to be stupid, in that it puts at risk his ally, and futile because he gets shot anyway. In this form, the story could hardly have served the Chronicler as a model for Josiah. But in the history of exegesis, Ahab and Jehoshaphat had been given a more dignified reading. Notably the verb התחפש, to disguise oneself, had been

32 Joosten, "Pseudo-classicisms in Late Biblical Hebrew." 
reinterpreted as "to dress up in armour" thus enhancing the picture of the Israelite King. Ahab and Jehoshapat were still disobedient kings, but at least they were kingly.

Finally, language. The re-use of the verb in the new meaning in 2 Chron 35:22 is surprising, but it finds many analogues in Chronicles and other Hebrew writings of the same period. Hebrew authors of the Persian and Hellenistic periods tried to write in the "biblical" style of earlier writings that had become authoritative, but they didn't wholly succeed. Old words they found in the earlier writings had been reinterpreted in the exegetical tradition. The later authors revived the use of the words with the new meaning. This remarkable phenomenon betrays an emerging attitude to Hebrew as an eternal language. Not a language learned from listening to one's parents, or in conversation, but a language one learns from studying scripture.

The pseudo-classical nature of the language of Chronicles is an important argument for the relative dating for the books of Kings and Chronicles. Some scholars, notably Graeme Auld, have argued that Chronicles and Kings are roughly contemporary works, with differing literary objectives. Analysis of the language of Chronicles makes this claim hard to accept. For a word to fall into disuse, its meaning to be forgotten, and a new meaning to be attributed to it, a lot of time needed to pass. The view that Chronicles is a post-exilic rewriting of a much earlier work-for the most part composed in the monarchic period but redacted in its final form during the exile-fits the linguistic facts much better. 